Institute of $\mathbf{F}_{\text {ood and }} \mathbf{A}_{\text {gricultural }} \mathbf{S}_{\text {ciences }}$

\title{
The Slugs of Florida (Gastropoda: Pulmonata) 1
}

Lionel A. Stange ${ }^{2}$

\section{Introduction}

Florida has a depauparate slug fauna, having only three native species which belong to three different families. Eleven species of exotic slugs have been intercepted by USDA and DPI quarantine inspectors, but only one is known to be established. Some of these, such as the gray garden slug (Deroceras reticulatum Müller), spotted garden slug (Limax maximus L.), and tawny garden slug (Limax flavus L.), are very destructive garden and greenhouse pests. Therefore, constant vigilance is needed to prevent their establishment. Some veronicellid slugs are becoming more widely distributed (Dundee 1977). The Brazilian Veronicella ameghini (Gambetta) has been found at several Florida localities (Dundee 1974). This velvety black slug should be looked for under boards and debris in vacant lots and cemeteries. Slugs are not commonly seen or collected because they are active mostly at night and inconspicuous during the day. In Spanish, they are called "babosas" from the verb "babear" (to drool), because of the copious amount of mucus they secrete. Slugs should be preserved in $75 \%$ isopropyl alcohol. It is best to drown them in water overnight in a covered container without air pockets so the bodies will be extended. After drowning they should be washed under running water to remove excess mucus before placing in preservative. Notes on the color of the mucus secreted by the living slug would be helpful in identification.

\section{Biology}

Slugs are hermaphroditic, but often the sperm and ova in the gonads mature at different times (leading to male and female phases). Slugs commonly cross fertilize and may have elaborate courtship dances (Karlin and Bacon 1961). They lay gelatinous eggs in clusters that usually average 20 to 30 on the soil in concealed and moist locations. Eggs are round to oval, usually colorless, and sometimes have irregular rows of calcium particles which are absorbed by the embryo to form the internal shell (Karlin and Naegele 1958). As a result, slug eggs often become more transparent as they grow. As soon as they hatch, young slugs (often lighter in color than adults) are active, crawl and feed if the temperature and humidity conditions are right. It is often several days before any plant injury becomes apparent, because they merely rasp away surface tissues. Slugs, especially young and hungry ones, can lower themselves from plants by mucus threads (Key 1902) that may extend several feet.

1. This document is EENY-087 (originally published as DPI Entomology Circular No. 197), one of a series of Featured Creatures from the Entomology and Nematology Department, Florida Cooperative Extension Service, Institute of Food and Agricultural Sciences, University of Florida. Published: June 1999. Revised: August 2002. This document is also available on Featured Creatures Website at http://creatures.ifas.ufl.edu. Please visit the EDIS Website at http://edis.ifas.ufl.edu. Additional information on these organisms, including many color photographs, is available at the Entomology and Nematology Department WWW site at http://entnemdept.ifas.ufl.edu/.

2. Lionel A. Stange, Florida Department of Agriculture and Consumer Services, Division of Plant Industry, Gainesville, FL.

The Institute of Food and Agricultural Sciences is an equal opportunity/affirmative action employer authorized to provide research, educational information and other services only to individuals and institutions that function without regard to race, color, sex, age, handicap, or national origin. For information on obtaining other extension publications, contact your county Cooperative Extension Service office. Florida Cooperative Extension Service/Institute of Food and Agricultural Sciences/University of Florida/Christine Taylor Waddill, Dean. 


\section{Identification}

Slugs are easily recognized by their soft, unsegmented bodies, dorsally covered completely or in part by a tough leathery skin (mantle). The head has a pair of upper tentacles bearing eyes, and a pair of shorter, olfactory ones. Positive identification of species often depends on internal anatomy. Color is often used, but considerable variation can occur.

\section{Key to Slugs of Florida including Intercepted Species}

1. Mantle covering all of the back of the animal (Figs. 1, 3-4) ....2

1'. Mantle covering only anterior part of the animal (Figs. 5-8, 11, 13, 15) . . . . 4

2(1). Breathing pore visible in short slit near anterior right mantle edge (Fig. 1); (Family Philomycidae) ..... Philomycus carolinianus (Bosc)

Length 50-100 mm. Albino (Hermann and Dundee 1959) and melanistic forms known but typically yellowish brown with 2 rows of dark spots along back. Feeds on fungi. Found under loose bark and aerial bromeliads. Native: Maine to Florida, west to Iowa and Texas. County records: Alachua, Collier, Jackson, Marion, Volusia.

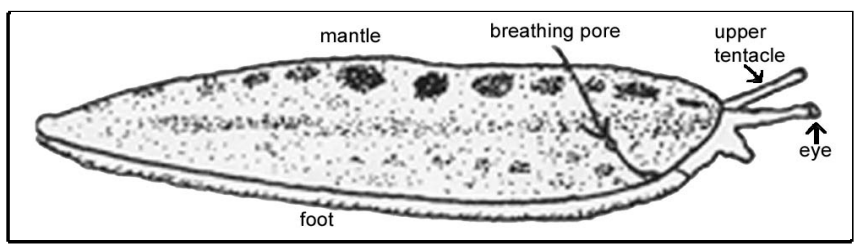

Figure 1. Slug Nomenclature. Credits: Division of Plant Industry

2'. Breathing pore not visible (Figs. 3, 4); (Family Veronicellidae) ..... 3

3(2'). Body velvety black in color (Fig. 3), length to about $50 \mathrm{~mm}$, elongate ..... Veronicella ameghini (Gambetta)

This Brazilian slug was first noticed at New Orleans in 1960 and now appears to be established in the Gulf states. Dundee (1974) records it from Pensacola, Miami, St. Augustine and Tallahassee. An aggregate of 14 slugs was found in October 1978,

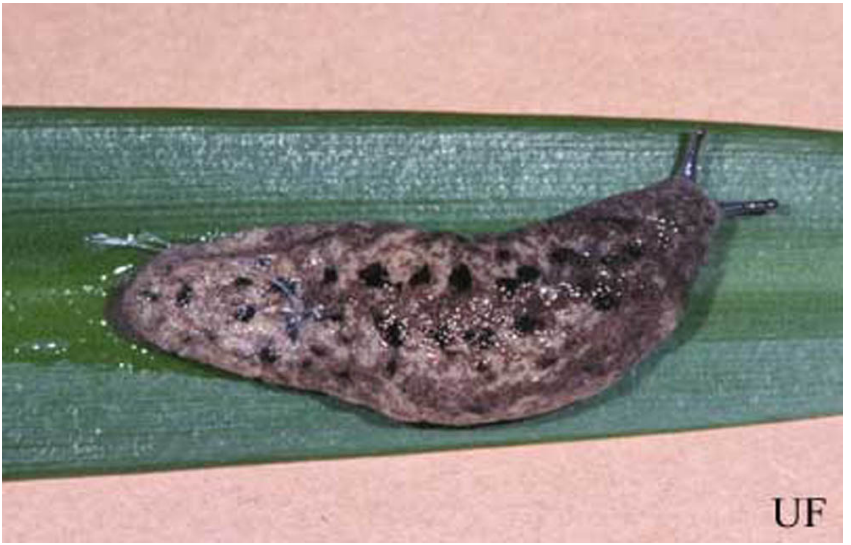

Figure 2. The slug Philomycus carolinianus (Bosc). Credits: Lyle Buss, University of Florida

under a large board lying upon grass near the Port of Pensacola. It is an urban slug found in vacant lots and cemeteries. Economic importance not known. Dundee (1974) records 3 other related species intercepted at Florida ports. County records: Dade, Escambia, Leon, St. Johns.

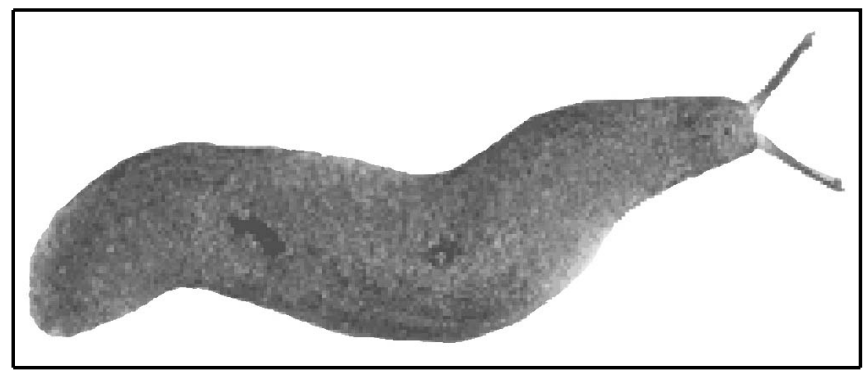

Figure 3. Veronicella ameghini(Gambetta) slug. Credits: Division of Plant Industry

3'. Body color (Fig. 4) ashy to brownish gray mottled with black, median whitish line usually flanked by longitudinal dark band on each side; length to $70 \mathrm{~mm}$, oblong ..... Veronicella floridana (Leidy)

This native slug was restricted to southern Florida and Cuba until recently. First noticed in Central Florida about 1968. Usually associated with St. Augustine grass but has been found damaging beans and tomatoes. County records: Alachua, Dade, Duval, Jackson, Hardee, Hillsborough, Lee, Orange, Volusia.

4(1'). Breathing pore located in anterior half of mantle (Fig. 5); back never keeled; posterior end rounded when viewed from above (Family Arionidae) Arion circumscriptus Johnson 


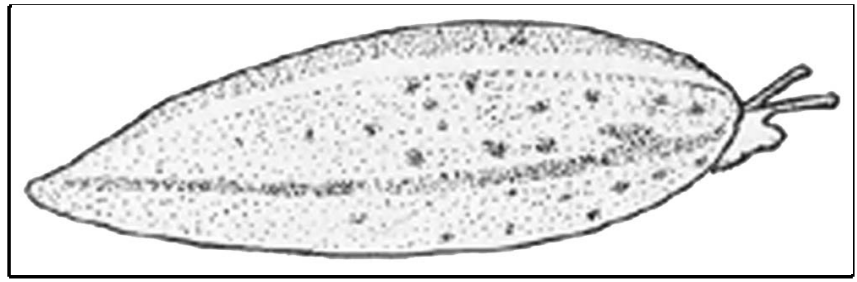

Figure 4. Veronicella floridana (Leidy) slug. Credits: Division of Plant Industry

Length 25-30 mm. Color pattern is distinctive from the other U.S. introduced species of Arion with the sole of the foot porcelain white. Intercepted in Florida from California on potted Pinus. Can cause considerable damage in greenhouses and vegetable and flower gardens. A. ater (L.) which attains a length of more than $70 \mathrm{~mm}$ has also been intercepted in Florida according to Dundee (1974).

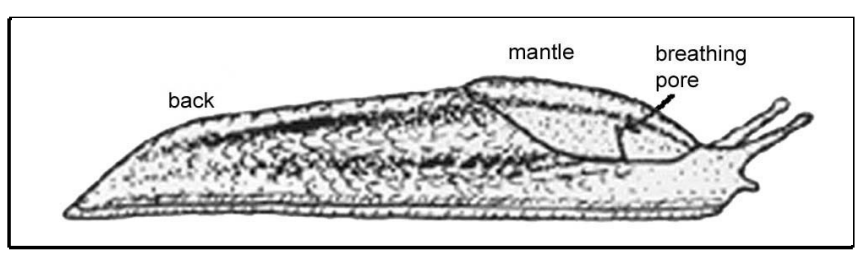

Figure 5. Banded slug. Credits: Division of Plant Industry

4'. Breathing pore located in posterior half of mantle (Figs. 6-8, 11, 13, 15); back keeled at least at posterior end which is pointed in dorsal view (Family Limacidae) . . . . 5 5

$\mathbf{5 ( 4 ' ) . ~ B a c k ~ s t r o n g l y ~ k e e l e d ~ f r o m ~ t h e ~ m a n t l e ~ t o ~}$ tip of tail (Fig. 6); mantle granulate with center part bound by groove ..... Milax gagates (Draparnaud)

Length 60-70 mm. Widely introduced in the U.S. from Europe, but in Florida only intercepted at ports. This slug usually burrows in the soil and feeds on roots.

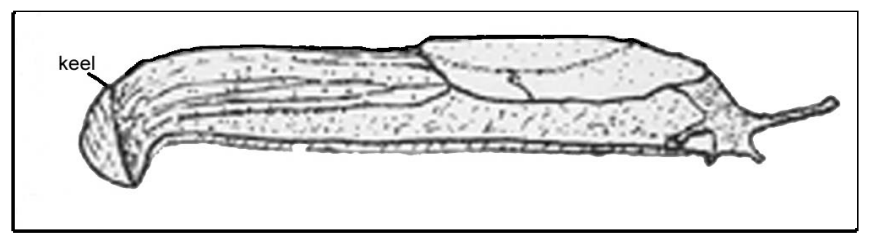

Figure 6. Greenhouse slug. Credits: Division of Plant Industry

$\mathbf{5}^{\prime}$. Back keeled only near posterior end; mantle concentrically wrinkled, without groove . . . 6

6(5'). Mantle and body with outstanding yellow or black spots (Figs. 7, 8); length $60-70 \mathrm{~mm}$. . . . . 7
6'. Mantle and usually back without well defined spots; size $60 \mathrm{~mm}$ or less . . . .8

7(6). Black-spotted; mucus colorless . . . . Limax maximus Linnaeus

Length 80-120 mm. Introduced: Massachusetts south to Virginia, west to Oregon and California. This is the largest of the European slugs introduced in the U.S.A. Important pest of gardens, greenhouses, cellars, and mushroom beds. Intercepted in Florida on grape leaves from Tennessee.

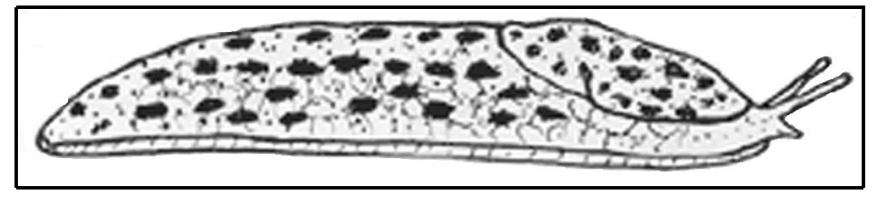

Figure 7. Spotted garden slug. Credits: Division of Plant Industry

7'. Yellow-spotted; mucus yellow . . . . Limax flavus Linnaeus

Length 75-100 mm. Found in urban and suburban gardens, greenhouses, and other cultivated places. One specimen found in 1965 in Tallahassee. Associated with celery, lettuce, roses. Native to Greece, Italy, Spain.

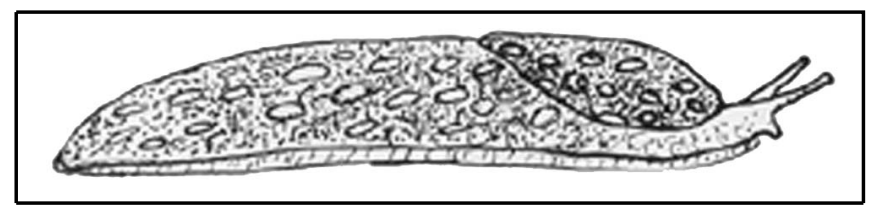

Figure 8. Tawny garden slug. Credits: Division of Plant Industry

$\mathbf{8}\left(6^{\prime}\right)$. Length $25 \mathrm{~mm}$ or less; mantle situated near middle of body (Fig. 11); mucus colorless . . . . . Deroceras laeve (Müller)

Smallest of the slugs in Florida. Widespread (Arctic to Central America) and highly adaptive. Feeds on great variety of plants in cultivated areas as well as in swamps, forests, etc. Can survive subfreezing temperatures (Getz 1959). Native throughout Florida from the Keys to Pensacola.

$\mathbf{8}^{\prime}$. Length $35 \mathrm{~mm}$ or more; mantle situated forward near head (Figs. 13, 15) ....9

$\mathbf{9}\left(\mathbf{8}^{\prime}\right)$. Exudes milky adhesive slime when irritated; breathing pore surrounded by pale ring; 


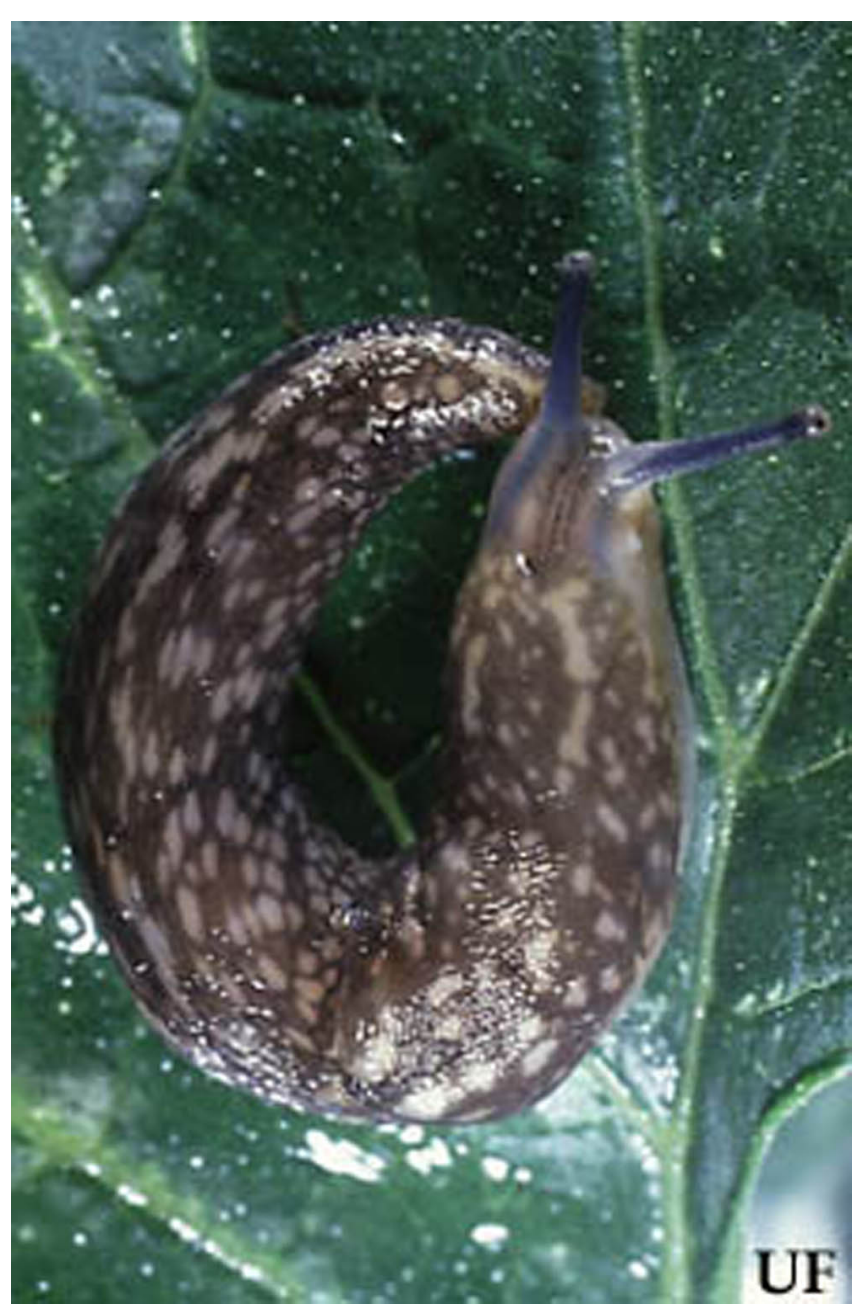

Figure 9. The tawny garden slug, Limax flavus Linnaeus. Credits: John L. Capinera, University of Florida

usually without well defined dark longitudinal bands . .... Deroceras reticulatum (Müller)

Length $35-50 \mathrm{~mm}$. Feeds on variety of plants below and above the soil surface such as young corn, cabbage, tomatoes, peas, strawberries, also ornamentals, mushrooms, and decaying vegetation. Widespread in U.S. except in Gulf states. Intercepted in Florida many times, mostly on ornamentals.

9'. Exudes watery slime; breathing pore not surrounded by pale ring with well defined dark longitudinal bands on mantle and back ..... Lehmannia poirieri (Mabille)

Length 50-60 mm. Introduced into New York, Arizona, California. Intercepted in Florida several times on Hydrangea from California. Recorded from Pensacola (Dundee 1974).

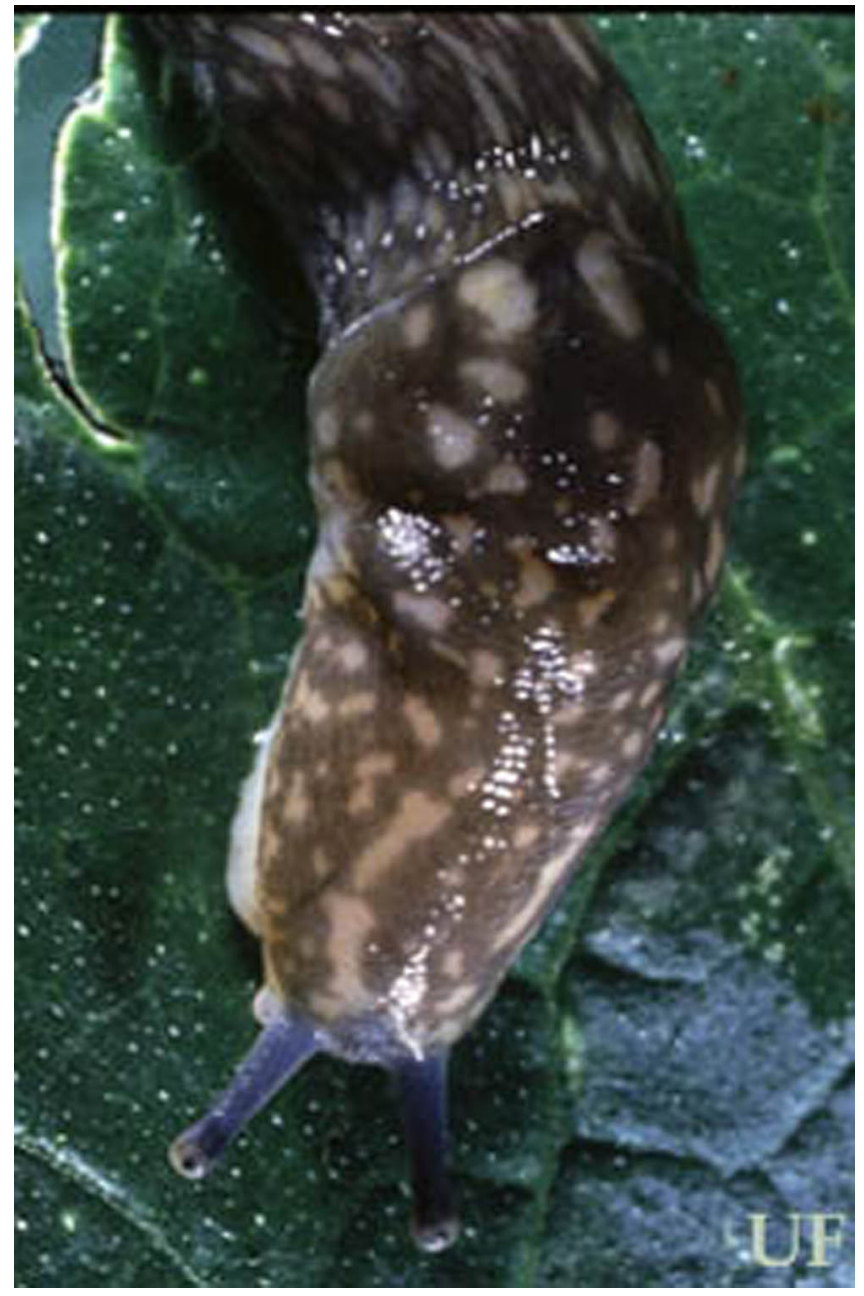

Figure 10. Detail of the mantle of $L$. flavus Linnaeus. Credits: John L. Capinera, University of Florida

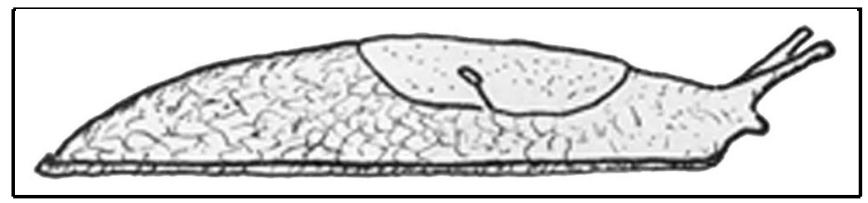

Figure 11. Marsh slug. Credits: Division of Plant Industry

\section{Economic Importance}

Little slug damage has been reported in Florida, but elsewhere some of the introduced European slugs have caused great damage on many vegetable plants in urban and suburban gardens and in cellars where they may attack potatoes. They are also fond of mushrooms. They also cause concern for the unsightly slime trails on ornamentals. They may transmit plant pathogens (Western et al. 1964). Little is known of their significance as intermediate hosts of disease parasites of animals (Chichester and Getz. 1068). Introduced slugs may disturb the natural 


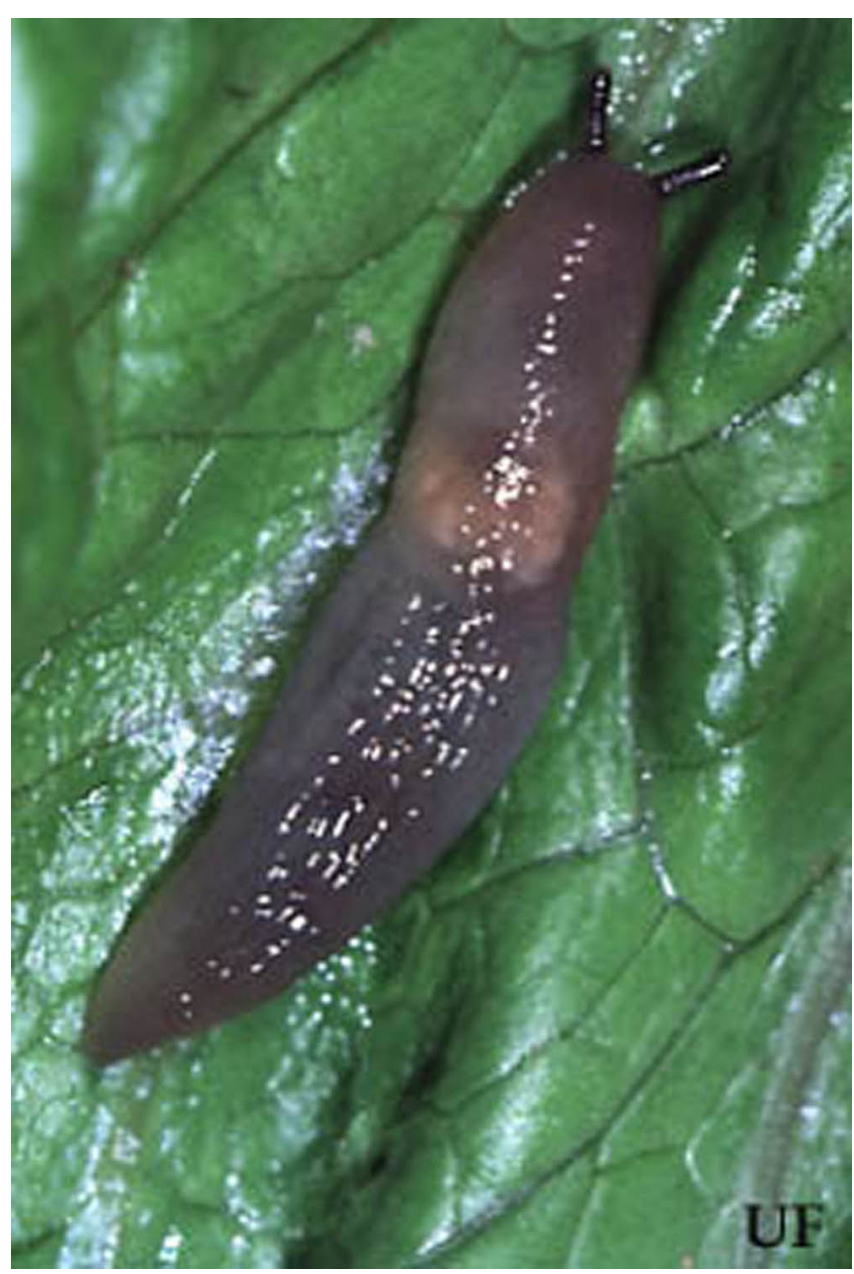

Figure 12. The marsh slug, Deroceras laeve (Müller). Credits: Paul. M. Choate, University of Florida

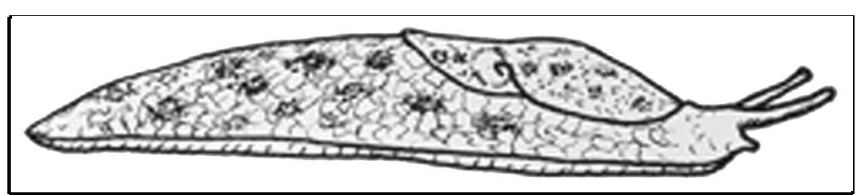

Figure 13. Gray garden slug. Credits: Division of Plant Industry

ecological balance in some areas, leading to the disappearance of native species.

\section{Management}

Natural enemies are relatively few (Stephenson and Knutson, 1966). Some birds, especially ducks, feed on slugs. Predator snails such as Euglandina rosea (Férussac) attack slugs. Few predaceous insects attack slugs, but the larvae of Lampyridae and adult Carabidae (Coleoptera) do so occasionally. There are some dipterous parasites (especially Sciomyzidae) (Trelka and Foote 1970). A few fungous diseases are known. Adverse climatic

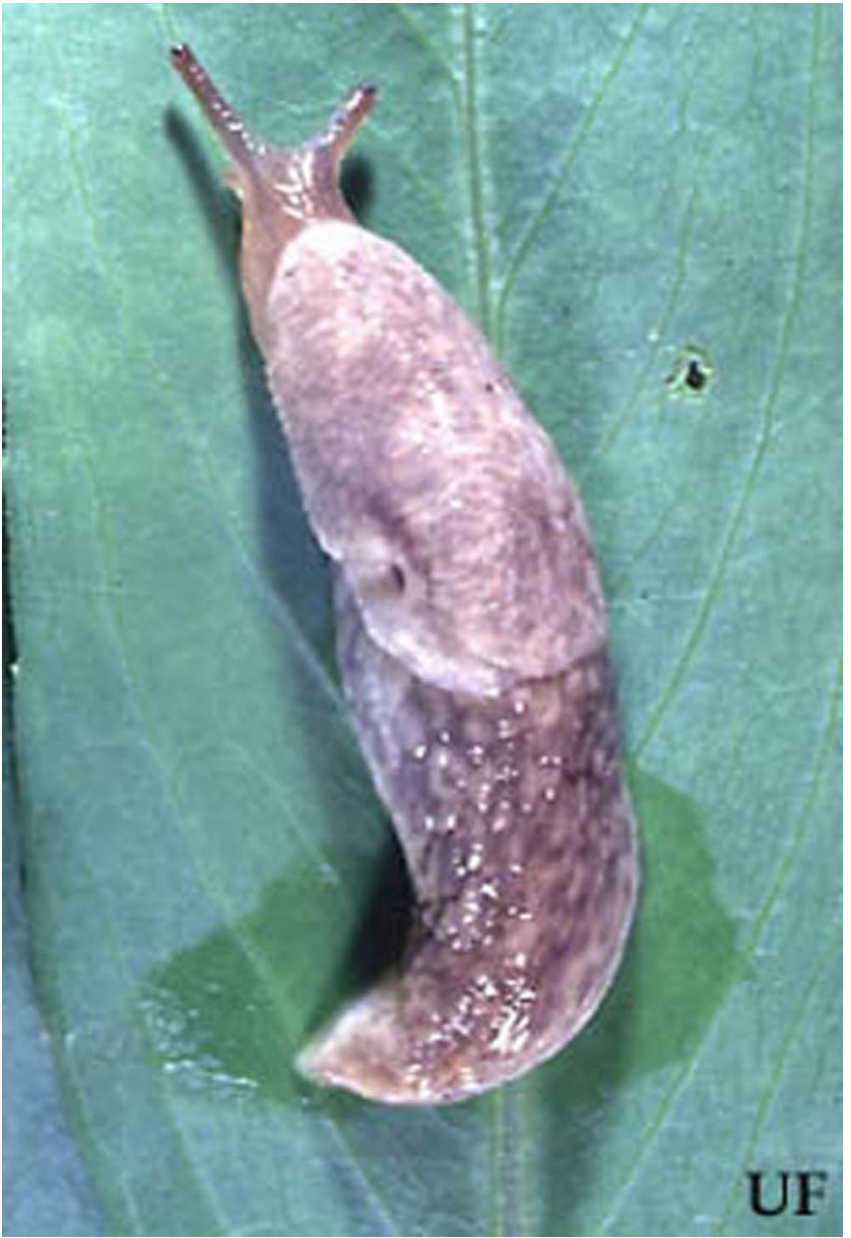

Figure 14. The gray garden slug, Deroceras reticulatum (Müller). Credits: John L. Capinera, University of Florida

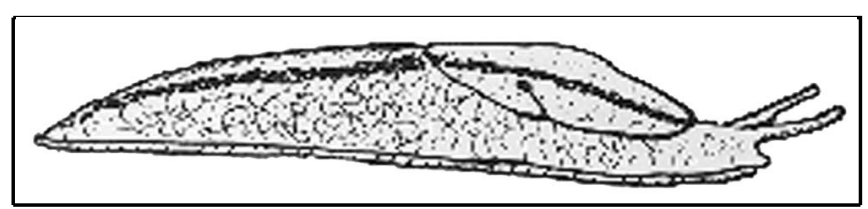

Figure 15. Lehmannia poirieri (Mabille) slug. Credits: Division of Plant Industry

conditions (e.g., dry, hot weather or excessive rains) serve to lessen depredations but do not appear to be of great significance. The rather poor slug fauna of Florida may be due to historic factors or perhaps to some natural factor as soil types. Clean surroundings will aid in controlling slug populations, and removal of boards, sacks, piles of brush, and other debris will limit slug numbers. When chemical control is indicated, the use of baits is recommended in commercial greenhouses.

Insect Management Guides for Ornamentals 
Insect Management Guide for Vegetables

\section{Selected References}

Burch, J.B. 1960. Some snails and slugs of quarantine significance to the United States. U.S. Dept. Agr. Res. Ser. 82: 1-73.

Burch, J.B. 1962. How to know the eastern land snails. The Pictured-Key Nature Series. Wm. C. Brown Co., Dubuque, Iowa. 214 p.

Chichester, L.F., and L.L. Getz. 1968. Terrestrial slugs. Biologist 1: 148-166.

Dundee, D.S. 1974. Catalog of introduced molluscs of Eastern North America (North of Mexico). Sterkiana 55: 1-37.

Dundee, D.S. 1977. Observations of the veronicellid slugs of the Southern United States. Nautilus 91: 108-114.

Getz, L.L. 1959. Notes on the ecology of slugs: Arion circumscriptus, Deroceras reticulatum and $D$. laeve. Amer. Midl. Nat. 61: 485-498.

Hermann, P.W., and D.S. Dundee. 1969. Notes on a light colored specimen of Philomycus carolinianus (Bosc). Nautilus 82: 133-137.

Karlin, E.J., and J.A. Naegele. 1958. Slugs and snails in New York greenhouses. Cornell Ext. Bull. 1004: 2-16.

Karlin, E.J., and C. Bacon. 1961. Courtship, mating and egg laying in the Limacidae. Trans. Amer. Microscop. Soc. 80: 399-406.

Key, H.W. 1902. On the mucus-thread of land-slugs. J. Conch. 10: 92-103, 153-165.

Lovett, A.L., and A.B. Black. 1920. The gray garden slug with notes on allied forms. Oregon Agr. Exp. Sta. Bull. 170: 1-43.

Pilsbry, H.A. 1968. Land Mollusca of North America. Acad. Nat. Sci. Philad. Monogra. 3, Vol. 2, pt. 2: i-xlvii, p. 521-1113.

Stephenson, J.W., and L.V. Knutson. 1966. A resume of recent studies of invertebrates associated with slugs. J. Econ. Ent. 59: 356-360.
Trelka, D.G., and B.A. Foote. 1970. Biology of slug-killing Tetanocera (Dipt. Sciomyzidae). Ann. Ent. Soc. Am. 63: 877-895.

Wester, R.E., R.W. Goth, and R.E. Webb. 1966. Transmission of downy mildew of lima beans by slugs. Phytopathology 54: 749.

White, W.H., A.C. Davis. 1953. Land slugs and snails and their control. U.S. Dept. Agr., Farmers' Bull. 1895 (Revised Edition): 1-8. 